\title{
Originalartikel
}

\section{Medikalisering av Cancerfamiljer ger Framtida Skuggor}

\section{Lisbeth Sachs}

Skaraborg Inst. Skövde, Osher Center for Integrative Medicicne, Karolinska Institute

lisbeth.sachs@swipnet.se

Sachs, L (2014). Medikalisering av Cancerfamiljer ger Framtida Skuggor, Tidsskrift for Forskning i Sygdom og Samfund, nr. 20, 47-57

När nu det genetiska arvet framstår alltmer som en förklaring till sjukdom och mänskligt beteende $i$ allmänhet behöver man ställa frågan hur sådana förklaringar påverkar människors uppfattningar om familj och släktskap över tid och i framtiden och i vilken utsträckning genetiska förklaringar strider mot vidare social utveckling. Idéer om genetiskt arv och cancersjukdom sätter familj och släktgrupper $i$ fokus. När en person informeras om anlag för cancersjukdom blir frågan om alla medlemmar $i$ en släktgrupp bör informeras och undersökas. Det kan gälla såväl från en medicinetisk utgångspunkt som från en känslomässig och ansvarskännande utgångspunkt bland diagnostiserade enskilda. Forskning kring ärftliga sjukdomar innebär en medikalisering av släktskap något som kan innebära stora förändringar för enskilda personer. Under en tid då familjestrukturer är mera flytande och mindre bestämda genom blodsband än tidigare kan man ställa frågan vilken betydelse en betoning av genetiskt arv som överförare av mänskligt beteende och släktskap kan fä. Inbyggt i begreppet genetiskt arv finns en betoning av familj och släkt som medier genom vilka ärftlighet flyter. Ett fall från en antropologisk studie illustrerar hur genetisk kargtläggning leder till medikalisering av släktskap ${ }^{1}$. 
Now that genetic inheritance is featuring more and more as an explanation of disease and human behaviour in general, a question that needs to be asked is how such explanations affect people's perceptions of family and kinship over time and in the future and to what extent genetic explanations conflict with broader social developments. Ideas about the genetic inheritance of cancer disease place the family and kin group in the spotlight, requiring all its members to be scrutinised. Research on inheritable diseases entails a medicalisation of kinship that reflects and promotes a view of family relationships at odds with the ongoing changes in the structure of families to day and in the future. At a time when family structures are more fluid and less determined by blood relationships than ever before we have an increasing emphasis on genetic inheritance as the transmitter of both human behaviour and kinship. Embedded in concepts of genetic inheritance is thus the notion that family and kin are the medium through which inheritance flows. One case from an anthropological study will illustrate how genetic mapping leads to the medicalisation of kinship.

\section{Inledning:}

Att mera exakt ange när termen medikalisering kom att bli ett kulturellt accepterat begrepp i vår svenska vokabulär är svårt. Det finns forskare som påstår att begreppet började användas först 1968 (Broom \& Woodward 1996) då det identifierades som en samhällelig tendens när det gällde att handskas med olika former av avvikelser. Avvikande beteende fick alltmer etiketten sjukdom. Under senaste seklets sekularisering kom exempelvis homosexualitet att betraktas som sjukdom snarare än moralisk överträdelse. Senare har begreppet medikalisering fătt en etablerad definition som en medicinsk möjlighet att både benämna avvikande beteende och att ge diagnoser i sin hälsokontrollerande verksamhet.

Den preventiva medicinen har kommit att utvecklas inte minst på grund av tekniskt avancerade undersökningsmetoder (Olin-Lauritzen \& Sachs 2001, 2011, Sachs 2012). Människor behöver inte längre presentera ett lidande för att anses sjuka. Med hjälp av så subtila analyser som på DNA-nivå kan man idag i laboratorier utifrån ett blodprov belägga inte bara avvikelser och patologi utan också mutationer på gener som kan förorsaka svår sjukdom i framtiden. Man talar inte bara om anlag för sjukdom hos en enskild individ utan potentiella anlag för alla de personer som har blodsband till densamma (Finkler 2000, 2001). Människor kan på så sätt komma att uppfattas som sjuka om de tillhör en familj med en 
speciell ärftlig sjukdom. Det gäller exempelvis familjer med en ärftlig variant av bröstcancer, ovarialcancer eller coloncancer. Ett anlag för sjukdom inom en familj kan komma att likställas med en latent sjukdom som gör människor beroende av kontroller, medicinsk övervakning och ibland förebyggande operationer (Sachs 1998, 1999, 2004). Det är bland annat via genealogiska kartor, familjeträd, som kartläggningen av ärftliga sjukdomar sker i möten mellan läkare och enskilda personer (Sachs 2001, 2012).

\section{Arvsanlagens betydelse för släkt och familj över tid}

Tidigare ansågs människor ärva sin status, sina rättigheter och skyldigheter, sin identitet och sociala position, genom familjen (Marcus \& Hall 1992). I dagens värld ser man inte på släktskapet som det som i första hand ger människor identitet och status. I västvärlden får en person sin sociala placering snarare genom att hävda sig individuellt genom eget arbete och egna val. I en tid då man med stor målmedvetenhet och stora resurser genomför forskning kring den mänskliga arvsmassan och det genetiska arvet blir möten mellan forskningens företrädare och den individuella människan i all sin valfrihet ett intressant fokus för studier av kulturförändring.

Nutidens medicinskt inspirerade intresse för genetiska samband är samtida med den alltmer upplösta familjen där okonventionella familje- och samlivsarrangemang blir allt vanligare. Homosexuella par med adopterade barn, ensamstående mödrar och fäder och olika uppsättningar av styvföräldrar och kollektiv är bara några som ingår i dagens familjebildningar. Dessutom pågår en alltmer utvecklad möjlighet att få barn med hjälp av surrogatmammor och genom spermadonationer. Men vilken betydelse får mot denna bakgrund fokuseringen på det genetiska arvet? Och i vilken utsträckning bidrar medicin teknisk medikalisering av släktskap till särskilda problem för personer som söker veta om sina arvsanlag? (Adelswärd \& Sachs 2002).

Familjen och släktskapet har under senare år mer och mer kommit att ingå bland de fenomen som medikaliseras. Släktskapsrelationer har givits en ny dimension som betonar felaktiga gener. Även om människor i allmänhet inte själva tror på eller kommit att anamma genetiska förklaringar till avvikelser av olika slag ger den nya forskningen på området föga möjligheter för individer att komma undan de sanningar som avspeglas i kartläggningen av mänsklig arvsmassa och DNA (Hubbard \& Wald 1997, Sachs 1999). De flesta människor har någon gång 
letat efter karaktärsdrag och specifika utseendemässiga drag hos sina nyfödda släktingar och genom det visat att de tror på överföring av genetiska anlag från föräldrar till barn. Men det människor idag får lära sig är att många delar av livet styrs av gener och att avvikelser på molekylärnivå går att studera och belägga.

Inom den antropologiska forskningen genom tiderna är det framförallt släktskapsfrågor i olika delar av världen som hjälpt till att reda ut såväl maktförhållanden som kulturellt viktiga relationer. Det finns mycket att säga om förhållandena även i det svenska samhällets familjestrukturer där släktskapsbanden om än i avtagande grad också har sin speciella betydelse för arv och giftermål. Man kan därför tänka sig att den genetiska forskningen på flera plan kommer att förstärka men också komplicera det som är släktskap med blodsband jämfört med exempelvis släktskap med ingifta eller adopterade barn, genom att arvsanlaget får allt större uppmärksamhet.

\section{Studier av genetisk kartläggning vid familjär cancer}

Den första konsultations möjligheten för genetisk kartläggning och värdering av framtida cancer risk i Sverige initierades 1991. Människor kunde söka specialistkliniken genom direkt kontakt, remisser av andra läkare, genom en släkting med en cancer diagnos eller tidigare bedömd ärftlig risk. Läkare som tog emot dessa personer gjorde sina bedömningar utifrån genealogier, släktträd, där man framförallt fokuserade på ärtliga faktorer. Genom familjens sjukdomshistoria kunde man ge en viss information kring framtida individuella risker och preventiva alternativ. Vid denna specialist mottagning var läkaren onkolog eller kirurg med subspecialitet inom genetik. Mottagningen var inte uppbyggd som genentisk "counceling" utan för en kombination av forskning och initial biomedicinsk information där en viss form av riskdiagnoser förmedlades. Dessa byggde på förekomst av cancersjukdom i släkten och gavs i form av procentsatser (Adelswärd \& Sachs 1998, 2002, Sachs, Taube, Tishelman 2001).

Deltagande observation vid denna form av konsultationer genomfördes av två forskare (Sachs och Tishelman) från augusti 1993 till och med juni 1994. Under denna tid tog läkarna emot tio nya patienter varje månad. Fyrtiofem sådana första informationssessioner observerades inom ramen för studien. Senare när forskarna blev fullt accepterade i miljön och med läkarnas tillstånd spelades trettiotre konsekutiva sessioner in på band. Bland dessa följdes 10 familjer med en så kallad "familjär cancer sjukdomsbild" under ett år och vidare fem kvinnor under ytterli- 
gare fyra år (Sachs 1998, 1999, 2001). Det gällde fem kvinnor som var de första att på genealogisk indikation bestämma sig för att operera sig profylaktiskt, det vill säga låta ta bort friska organ i syfte att reducera sin risk för framtida sjukdom. Under 1996-97 genomfördes också ett antal intervjuer med elva kvinnor som givits möjligheten att genom blodprov få sina anlag för bröstcancer belagda. Denna möjlighet fick man på grund av att bröstcancergenerna BRCA 1 och 2 upptäcktes under våren 1996.

Här i retrospekt hävdar jag att den genetiska genealogin hjälper till att medikalisera familj och släkt över tid. Hur det sker vid samtal där människor söker klarhet om sin risk för anlag och framtida sjukdom med läkare som använder släktträdet som fokus beskrivs. Intervjuer med elva kvinnor som berättar hur familjebanden fått nytt innehåll i deras liv efter information om anlag utgör också material som används.

Sedan denna studie genomfördes har genetisk screening och rådgivning blivit tillgänglig på ett mera rutinmässigt sätt i Sverige. Den medicinska litteraturen på området är omfattande. Etiska frågor har kommit att framträda alltmer och medvetenheten om att människor ställs inför svåra val är mera uttalad. Inom det medicinskt antropologiska området har inte mycket publicerats specifikt om genetiska sjukdomar och medikaliseringen av släktskap, något som utgör fokus i detta arbete. Avsikten här är framförallt att pröva tankar kring hur medicinsk teknik ger möjligheter till att medikalisera anlagsbärare av genetiskt betingad cancer något som också kan på olika sätt komma att påverka släktskapsrelationer nu och i framtiden.

\section{Genealogin som verktyg}

Tiderna har förändrats och släktträdet i form av en genealogisk karta står inte längre enbart i fokus för etnografiskt fältarbete eller släktforskning överhuvudtaget. Enkla genealogiska diagram utgör numera också en populär form av professionell stenografi i mycket skilda sammanhang. Bland annat har en form av användning vuxit fram vid sidan av annan släktforskning och blivit mycket viktig, den som ska utreda och belägga genetiska anlag för cancersjukdom och andra sjukdomar som kan drabba i framtiden.

Trädet växer fram som en karta över en släkts sjukdomshistoria. En medicinsk stamtavla utgörs av "a family tree constructed from a person's knowledge of the family relations and the conditions each may or may not have had" (Richards 
1996:250). Men även om detta är en persons minnesbild utgör medicinska släktträd "a basic investigative tool" i den genetiska kliniken (ibid). Släktträdet, såsom det ritas upp vid den genetiska informationen, utesluter de personer som inte är bundna till "ego" genom blodsband. Dessutom är bara de personer som har eller har haft cancer eller som befinner sig i riskzonen för att bära på anlaget intressanta.

Hur går det egentligen till när människor får sina diagnoser via genealogin? Vilken form har sådana samtal? Hur avspeglas den nya tidens osynliga hot i samtal mellan medicinska företrädare och deras klienter? Och hur talar människor i efterhand om dessa nyvunna kunskaper? I det som följer finns exempel på hur dessa frågor har uppstått och hur de finns med i varje enskilt fall.

Varje samtal som har genealogin som utgångspunkt har en viss form. Läkaren frågar först om personen ifråga har några barn. Nästa fråga rör syskonen och deras barn. Långsamt tar man sig sedan igenom föräldrar och deras syskon, deras respektive barn och slutar vid mor- och farföräldrarna. Som avslutning gör läkaren en bedömning:

»och som det är nu så är det två stycken med magsäckscancer i alla fall. Två av dina bröder, och lungcancer, pappa och cancer i njure och kanske något annat hos mamma, det får man väl kolla också.« (Med utgångspunkt från genealogin kan läkaren gå vidare och ta fram journaler, sparade vävnadsprover, blod etc från avlidna.)

Ett samtal kan också mera direkt tala om att det handlar om en ärftlig problematik där hela familjen blir delaktig. Ett exempel på detta finns i ett av samtalen mellan en av de elva kvinnorna och läkaren:

»men nu har vi ju bedömt det så här eftersom det finns så pass många fall av bröstcancer, och även nån som hade äggstockscancer, att det är en bröstcancerfamilj, så att säga, men...«

\section{Den genetiska kartläggningens konsekvenser}

Den genetiska kunskapen kan förändra förhållandet till den grupp som en människa måste inkludera i sina egna högst personliga beslut och ta ansvar för. I sin tur kan det leda till att gränserna för familj, släkt och nära blir problematiska och kommer att ändras. Kunskap om genetiska samband kan få betydelse för relationerna mellan den enskilda människan och nu levande, ibland helt okända perso- 
ner som hon tidigare inte haft kontakt med eller valt att inte ha kontakt med samt till sist mellan henne och ännu ej födda släktingar.

Samtalen med en av kvinnorna som efter genealogisk kartläggning fått sina anlag för bröstcancer bekräftade genom blodprover visar vilka konsekvenser kartläggningen av släktens sjukdomshistoria fått för dem.

"Utan det där så hade jag inte...då hade min släkt varit väldigt liten. Då hade den varit jag och min moster kanske. Ja, min morfar då och sen hade det stannat där.

Och så ja, min mamma. Jag kan känna att det tar så stor del i min släkthistoria det här med anlaget så att det är lätt att det fokuseras kring också, cancer och anlaget, det är det som är min släkthistoria nånstans, det är ett anlag som egentligen inte är nåt positivt. Det är det jag fick av min mamma.

Mmm, det har fört in mera komplicerade relationer. Hon (min moster) ringer till mig och säger att hon också är orolig för en kusin till min mamma som jag aldrig har träffat, och då har vi genast en gemensam nämnare. Men vår släktskap blev så komplicerad. Det blev så tydligt att man på nåt sätt är kött och blod också, som är lite nytt. För det är stick i stäv med vad man vill bli. Man är ändå en del av nåt annat och man vill inte vara beroende. Så det är inte bara positivt. Ja, det är ju ingen rolig gemensam nämnare. Man är fast i det här för all framtid...."

Kvinnan här visar hur hon väljer släkt på basis av känslomässiga band. Men i och med att den nya genetiken betonar släktrelationer på basis av blodsband snarare än val blir hennes släkt något som tränger sig på. Det gemensamma är inte hur hon känner utan "den gemensamma nämnaren" blir något negativt. Här kan man tala om att det sker en medikalisering av hennes släkt. Med medikaliseringen av släktskap är inte längre individen den enda som kan välja hur behandlingen ska se ut. Det genetiska arvet förenar, ofta ofrivilligt, kvinnan med hennes familj och släkt utöver den lilla kärnfamiljen och ställer nya krav på henne.

"Och det som egentligen gjorde mig, som var svårast under den här perioden (..) det var när jag fick klart för mig att jag var drabbad men att den här genen, min bror skulle kunna vara bärare av genen. Jag trodde att det här var nånting som bara gick på den kvinnliga sidan.

Men när jag förstod att min bror var bärare, att mina brorsdöttrar skulle kunna vara drabbade också, och vara bärare, ha genen då. 
Och dom är då 32 och 25. Och då kändes det som om herregud, jag är ju i alla fall då gammal, jag har ju mina barn. Jag har ju på nåt vis gjort min bit. Men att dom står precis i början, och hur kommer ett sånt här besked att påverka dom. Det var nog det som var svårast och jag kände litegrann att det är jag. Det är jag som kommer med det här budskapet. Det är jag som på nåt vis drabbar deras liv, så att jag kände mig litegranna som att det är jag som blir boven. Det är jag som är skurken.

Ja, jo för det kändes, det är jag som går in och dramatiskt ändrar det här, och det kände jag ju då även att jag var tvungen att göra med övriga släkten, eftersom vi är då ganska många. Min mamma har många syskon.

Och eftersom det då involverade så att säga, inte bara då systrarna utan även då hennes bröder och deras barn så att säga."

Medikaliseringen av släktskap skapar en ny dynamik kring familjer. I detta fall leder kvinnans insikter till svårigheter med hur, och om, hon ska informera men också till skuldkänslor. Även om det är ovanligt att människor anklagar sina släktingar för att ha förorsakat sjukdom eller risk för sjukdom finns det mycket starka känslor bland familjemedlemmar som blir medvetna om blodsbandens betydelse för riskerna de delar och som kan leda till sjukdom hos deras barn och eventuella barnbarn i framtiden.

Vetskapen hos en av kvinnorna i studien att hon själv men inte hennes syster befann sig i risk för framtida allvarlig sjukdom genom ett arvsanlag gav deras relation en ny dimension där öppenheten mellan dem blev lidande. Enligt kvinnan i fråga är det framförallt hennes syster som bär på den tyngsta bördan. Nutiden flyter samman med framtiden och ger upphov till tveksamheter hos henne när det gäller att föda barn. Genealogin visar att de alla befinner sig i en bröstcancerfamilj och medikaliserar därigenom hela släkten. Men i och med att gentester blivit möjliga vid bröstcancer kan man bekräfta vilka som bär på anlaget. Icke anlagsbärare kan strykas ur genealogin som ointressanta och ett delvis nytt släktträd växer fram där de utan anlag kan jämföras med ingifta. De är inte av intresse för familjens sjukdomshistoria i framtiden.

\section{Diskussion}

Samtal som har som syfte att kartlägga familjers sjukdomshistoria har en struktur och en underliggande plan som bygger på ett speciellt mönster av frågor. I och 
med frågorna blir personen som svarar långsamt medveten om den eventuella hotbild som föreligger. Till synes helt alldagliga frågor får en alldeles speciell och allvarlig betydelse när de resulterar i ett mönster av relationer kring levande och döda.

Medicinska släktträd kan förstås som visuella verktyg eller "inscriptions" (Latour 1990). Latour har tagit begreppet från Derrida (1973) för att skapa ett redskap som är mer basalt än skrivandet och som därmed gör det möjligt att transformera materiella beståndsdelar till diagram. I fallet med genealogin används sådana s k inscriptions av kliniker och laboratoriepersonal för att göra den osynliga kunskapen känd för familjen och därmed göra familjen och familjens sjukdom till ett objekt för medicinsk intervention såväl i nutid som i framtiden. Man kan säga att medicinska genetiska kartläggningar omfattar en serie översättningar från en väv av svar och muntliga berättelser till en sekvens av visuella inskriptioner. En sådan sekvens utgör i sin tur delar av större inskriptioner där medicinska släktträd förenas med en visuell uppsättning kanske cytogenetiska eller molekylära biologiska testresultat (Nykaga \& Cambrosio 1997, Forss 2005). I fallet med genetisk kartläggning blir individer inte bara placerade i sina familjesammanhang på ett speciellt sätt, de blir också definierade genom att de sammanförs med genetiskt baserade föreställningar om risk vilket i sin tur kan leda till nya sätt att se på familj och släkt.

Transkriptioner av genealogin karaktäriseras av att de oundvikligen leder fram mot en karta där alla sådana familjedata som inte uppfattas vara bundna till det specifika sjukdomsproblemet utesluts. De visuella relationerna mellan figurerna i genealogin ger en vision av familjen som en helhet - allt om familjen finns på papperet - och sjukdomen blir en egenskap eller egendom som angår hela familjen och som den äger kollektivt. På så sätt refererar ett familjeträd till en kollektiv, sjuk kropp och blir på så sätt det visuella minnet över familjens sjukdom i nutid så väl som i framtiden.

Kartläggningen innebär att man representerar något som har kartan som analogi. Kartor ger en lokaliserings indikation (här är jag) med en ensidig utgångspunkt som förser personen med en utgångspunkt varifrån världen kan upptäckas. På samma sätt utgör den genetiska förklaringen till ärftlig sjukdom en utgångspunkt i en karta där journaler och även DNA prover kan tolkas och översättas. Genom att ge olika personer i ett familjeträd möjlighet till sin utsiktspunkt blir trädet mera fullständigt och komplext. Det innebär också att det är helheten som är fokus för uppmärksamheten och intresset från forskarens sida. Familjeträd avtäcker inte bara det som är synbara sjukdomsmanifestationer utan också osynliga, 
icke manifesta sjukdomar där bärare av anlag kan identifieras. Här kan man tala om en slags överproduktion av familjesjukdom där just begreppet medikalisering får sin rätta innebörd genom att man skapar existensen av nya patologiska kategorier såsom anlagsbärare.

En av de stora frågorna som antropologerna ställer sig idag är om själva begreppet släktskap i bemärkelsen att tillhöra samma familj och att känna sig besläktad med vissa personer är något som förändras på grund av medicinska framsteg. Medikaliseringen av släktskap sker i samband med ambitionen att via genealogin kartlägga människors delaktighet i ett sjukligt arv. Det sker genom att man i och med genetiken betonar gemensam identitet mellan personer som kanske inte har haft något med varandra att göra under sin historia eller i nutid. Man betonar blodsband före affinala band. Men splittringen sker också inom medikaliserade släkter genom nyvunna möjligheter att belägga arvsanlag via genetiska test. Genetiken förenar och splittrar. Dagens individualister och autonoma människor som vant sig vid att välja sin familjtillhörighet har nya utmaningar i medikaliseringens fotspår.

\section{Notes}

1. En tidigare version finns publicerad i Scand.J of Publ.Health 2004 men är här uppdaterad och reviderad.

\section{Referenser}

Adelswärd, V. \& Sachs, L. (1998) Risk discourse: recontextualization of numerical values in clinical practice. Text 18:191-210.

Adelswärd,V. \& Sachs, L. (2002) Framtida Skuggor: samtal om risk, prevention och den genetiska familjen. Lund: Arkiv Förlag.

Broom, F.H. \& Woodward, R.V. (1996) Medicalization Reconsidered: towards a collaborative approach to care. Journal of Health and Illness 18:357-378.

Finkler, K. (2000) Experiencing the New Genetics: Family and Kinship on the Medical frontier. Philadelphia: University of Pennsylvania Press.

Finkler, K. (2001) The Kin in the Gene: The medicalization of family and kinship in American Society. Current Anthropology, 2:235-249.

Hubbard, R. \& Wald, E. (1997) Exploding the Gene Myth. Boston: Beacon Press.

Forss, A. (2005) At the margin of health and normality. PhD Thesis, Department of Nursing. Karolinska Institutet, Stockholm, Sweden.

Latour, B. (1990) Drawing things together. I Lynch, M \& Woolgar, S. (utg.) Representation in Scientific Practice. Cambridge, MA: MIT Press. 
Marcus, G.E. \& Hall, P.D. (1992) Lives in Trust: The Fortunes of Dynastic Families in Late Twenties Century America. Boulder, Colo.: Westveiw Press.

Nukaga,Y. \& Cambrosio, A. (1997) Medical pedigrees and the visual production of family disease in Canadian and Japanese families, I Elston, M.A. (utg.) The Sociology of Medical Science \& Technology. Oxford: Blackwell Sociology of Health \& Illness Monograph No 3.

Olin-Lauritzen, S. \& Sachs, L.(2001) Normality, risk and the future: implicit communication of threat in health surveillance. Sociology of Health and Illness, Nr 4, 497-516.

Richards, M. (1996) Family, kinship and genetics. I Marteau, T. \& Richards M.(utg.) The Troubled Helix: Social and Psychological Implications of the New Human Genetics. Cambridge: Cambridge University Press.

Sachs, L. (1997) The Diagnosis of Risk - implications for the Quality of Life. In: Cancer, Aids and the Quality of Life, Levy,J.A et al. eds. New York: Plenum Press.

Sachs, L. (1998a) Att Leva med Risk: fem kvinnor, gentester och kunskapens frukter. Stockholm:Gedins Förlag.

Sachs, L. (1998b) The Visualization of the Invisible Body. In Identities in Pain. Frykman,J. ed. Lund:Dept of European Ethnology. Nordic Academic Press.

Sachs, L. (1999) Knowledge of no Return: getting and giving information about genetic risk. Acta Oncologica 38:735-741.

Sachs, L. (2001) The new age of the molecular family. Paper presenterat vid ESPO konferensen i Heidelberg, June, 2001.

Sachs, L. (2004) The new age of the molecular family: an anthropological view on the medicalisation of kinship. Scand. J. Of Publ. Health, 32;1:24-29.

Sachs, L. (1996, 2012) Sjukdom som Oordning. Natur \& Kultur, Stockholm.Sygdom som Ubalance. Dansk udgave: Forlaget Fremad A/S Köpenhamn, 1999.

Sachs, L., Taube, A. \& Tishelman, C. (2001) Risk in Numbers: Difficulties in the transformation of genetic knowledge from research to people. Acta Oncologica, 4:445-453.

Szasz, T. (1963) Law, Liberty and Psychiatry: An Inguiry into the Social Uses of Mental Health Practices. New York: Macmillan.

Tishelman, C. \& L. Sachs, (1998) The Diagnostic Process and the Boundaries of Normality. Qualitative Health Research, 1:48-60. 